12 Gottdiener JS, Katin MJ, Borer JS, Bagharach SL, Green MV. Late cardiac effects of therapeutic mediastinal irradiation. $N$ Engl $₹$ Med 1983; 308: 569-72.

13 Stewart JR, Fajardo LF. Radiation-induced heart disease; an update. Progr Cardiovasc Dis 1984; 27: 173-194.

14 Burns RJ, Bar-Shlomo BZ, Druck MN, et al. Detection of radiation cardiomyopathy by gated radionuclide angiography. Am f Med 1983; 74: 297-302.
15 Hancok SL, Donaldson SS, Hoppe RT. Cardiac disease following treatment of Hodgkin's disease in children and adolescent. ₹ Clin Oncol 1993; 11: 1208-15.

16 Lipshultz SE, Sallan SE. Cardiovascular abnormalities in long-term survivors of childhood malignancy. $\mathcal{f}$ Clin Oncol 1993; 11: 1199-1203.

\title{
Medical Anniversary SVEN LOFGREN, 1 March 1910
}

Sven Lofgren (1910-78) was born in Stockholm where he received his medical training and where he married a Swedish physician, who bore him four children. His medical life revolved around St Goran's Hospital where he came under the scientific influence of Westergren and Schaumann. Sven grasped the baton handed to him by Schaumann and his own elegant studies brought the mysterious disease sarcoidosis out of the shadows and into the limelight as a common disorder with a good prognosis. During the war years he analysed 185 cases of erythema nodosum and found 15 patients in whom sarcoidosis was probable, despite lack of histological proof. In a second Swedish survey published in 1953 he obtained histological proof of sarcoid tissue in one-quarter of a series of 113 patients with erythema nodosum and bilateral hilar lymphadenopathy and, quite rightly, this combination has been known as Lofgren's syndrome ever since. Once he had defined it, the rest of the world recognised it.

Lofgren died on 17 June 1978. His lifework was at St Goran's Hospital, where he succeeded Westergren as head of the lung clinic and where he inherited from Schaumann the old roll-top desk which was a permanent feature of Sven's office furniture. I wonder who uses it now? Schaumann donated more than just his roll-top desk for they were good friends and colleagues at St Goran's. Schaumann (1879-1953) was the old experienced dermatologist turned multisystem physician and Lofgren the young chest physician. In 1971, Sven was awarded the title of Professor, an unusual honour in Sweden for a physician practising outside a university department. 